\title{
Pleistocene karyotypic divergence in Hoplias malabaricus (Bloch, 1794) (Teleostei: Erythrinidae) populations in southeastern Brazil
}

\author{
Uedson Pereira Jacobina, Edson Paiva and Jorge Abdala Dergam
}

\begin{abstract}
The lacustrine system of the middle rio Doce basin is considered a paradigm of Pleistocene geomorphology. In these lakes, two Hoplias malabaricus karyomorphs $(2 \mathrm{n}=42 \mathrm{~A}$ and $2 \mathrm{n}=42 \mathrm{~B})$ live in sintopy in Carioca Lake. Cytogenetic analyses were performed on 65 specimens from 8 lakes (including Carioca Lake) to determine the distribution and relative frequency of these karyomorphs and the degree of cytogenetic divergence caused putatively by recent geographic isolation. All fish were $2 \mathrm{n}=42 \mathrm{~B}$ karyomorphs, except for 1 specimen from the Marola Lake, which was $2 \mathrm{n}=42 \mathrm{~A}$. Among-population variation was especially high for C-banding patterns. Other characters such as X chromosome size and $\mathrm{CMA}_{3}$ /DAPI also varied among populations. Our results suggested that the karyotype of $H$. malabaricus is able to respond rapidly to geographic isolation, and revealed that heterochromatic variation may represent the lowest hierarchical level of chromosomal evolution.
\end{abstract}

O sistema lacustre da bacia do médio rio Doce é considerado um paradigma da geomorfologia do Pleistoceno. Nestes lagos, dois cariomorfos de Hoplias malabaricus $(2 \mathrm{n}=42 \mathrm{~A}$ e $2 \mathrm{n}=42 \mathrm{~B})$ vivem em sintopia na lagoa Carioca. Análises citogenéticas foram realizadas em 65 amostras de 8 lagos (incluindo lagoa Carioca) para determinar a distribuição e frequência relativa destes cariomorfos e o grau de divergência citogenética aparentemente causada pelo isolamento geográfico recente. Todos os peixes apresentaram o cariomorfo $2 n=42 \mathrm{~B}$, com exceção de 1 espécime da lagoa Marola, que foi $2 \mathrm{n}=42 \mathrm{~A}$. Entre as populações, a variação foi especialmente elevada nos padrões de bandamento C. Outros caracteres como o tamanho do cromossomo X e os padrões de $\mathrm{CMA}_{3}$ /DAPI também variaram entre as populações. Nossos resultados sugerem que o genoma de $H$. malabaricus é capaz de responder rapidamente ao isolamento geográfico, revelando que a variação de heterocromatina pode representar o nível hierárquico mais baixo de evolução cromossômica.

Key words: Conservation genetics, Karyotype evolution, Middle rio Doce Valley, Sympatry.

\section{Introduction}

The Neotropical region is considered the richest in freshwater species of fish in the world (Schaefer, 1998). However, the rates of change of character state are largely unknown. To address the extent of biological variation at different divergence levels, studies must focus on spatial scales with well established and dated geomorphological histories, a rather unusual condition in the Neotropics. Due to their inherent physiological constraints, freshwater fish are considered particularly informative of the geological past (Myers, 1938) and several studies have addressed the informative value of fish distribution patterns. Molecular data are particularly suitable to reflect different levels of divergence (Page \& Holmes, 1998; Graur \& Li, 1999) and they have been successfully applied in icthyological research (e.g., Sivasundar et al., 2001; Montoya-Burgos, 2003; Santos et al., 2009). Mitochondrial DNA divergence has been considered as a bridge between micro and macroevolutionary events (Avise, 2000), and this approach remains the choice for phylogeographic studies (Beheregaray, 2008). On the other hand, an insight of what is to be expected at shallow levels of divergence for karyotypical data is still lacking for Neotropical fish, where cytogenetic studies are usually conducted in conditions in which time, dispersal, and vicariance are largely unknown factors.

In southeastern Brazil, the middle rio Doce Valley lacustrine system is considered the paradigm of upper Pleistocene geomorphology (Meis \& Moura, 1984; Petri \& Fúlfaro, 1983). This extensive 150-lake system originated during two processes, the first dated 10,000 - 14,000 years (Meis \& Monteiro, 1979) and a more recent dated 7,800 (+/$250)$ to $3,365(+/-155)$ years (Tundisi \& Meis, 1985). These lakes comprise $30 \%$ of the species of fish of the rio Doce basin (Godinho \& Vieira, 1998) and are characterized by distinct environments and varying degrees of natural eutrophication (Espíndola et al., 2003), which presumably impose different ecological conditions upon the aquatic fauna.

Universidade Federal de Viçosa, Departamento de Biologia Animal, 36571-000 Viçosa, MG, Brazil. uedsonbio@gmail.com, edson.paiva@cenibra.com.br,jdergam@gmail.com 
To date, the only study using a molecular ecology approach and an explicit temporal perspective was carried on by Dergam et al. (2002). Their study suggests that the population of $H$. malabaricus in each lake represents an ecological and evolutionary unit where migration, demographic, selective, and neutral factors affect allelic frequencies. Unfortunately, this lacustrine system is also the arena for rapid local extinction of native species, as a direct result of invasive species (Sunaga \& Verani, 1983; Godinho et al., 1994; Vono \& Barbosa, 2001; Latini, 2004, 2005). Historical records indicate that in three lakes, the presence of peacock bass Cichla monoculus and piranha Pygocentrus nattereri caused the extinction of half of the native species and jeopardize the recruitment of most of the remaining indigenous species (Godinho et al., 1994). In 2005 an extensive survey indicated that invasive species had found their way to $90 \%$ of the lakes in the rio Doce State Park (Latini, 2005). As a long term-effect, exotics have apparently caused inverted cascade processes that affect the lowest trophic levels (Pinto-Coelho et al., 2008).

Despite this trend of destruction, the special geological and environmental features of this lake system qualified it for the highest priority class for conservation (MMA/SBF 2000). One of the resilient native species is Hoplias malabaricus (Bloch, 1794), the common trahira (Dergam et al., 2002), which is also ubiquitous in the Neotropical region (Berra, 2007). So far, $7 \mathrm{H}$. malabaricus karyomorphs have been described (reviewed in Bertollo et al., 2000) in sympatric and in allopatric conditions (Born \& Bertollo, 2000, 2006; Rosa, 2006). Among Brazilian coastal basins, the rio Doce basin is unique in harboring 2 karyomorphs that occur in sympatry: karyomorph $2 n=42$ A characterized by a chromosomal formula of 11 pairs of metacentric and 10 pairs of submetacentric chromosomes and the absence of sex chromosomes. Karyomorph B is also $2 n=42$, but it has 12 pairs of metacentrics, 8 pairs of metacentrics and a XX/XY sex chromosome system composed of 1 pair of subtelocentrics in females and a heteromorphic pair (a submetacentric and a subtelocentric). Both karyomorphs were found in sympatry only in the Carioca Lake (Ferreira et al., 1989; Born \& Bertollo, 2006). In this lake karyomorph A is less common, occurring in 1 out of 22 (Ferreira et al., 1989) and in 1 out of 5 specimens (Born \& Bertollo, 2006). Karyomorph B has also been collected in Lakes Ferrugem, Amarela, and Azul (Born $\&$ Bertollo, 2000) and it is widespread in the headwaters of the rio Doce (Dergam, unpubl.). In this study we carried out cytogenetic analyses in samples of $H$. malabaricus from some lakes of this system (including the Carioca Lake) to answer the following questions: what is the distribution and preponderance of karyomorphs A and B in the lake system?; and has Pleistocene isolation promoted cytogenetic divergence among populations?

\section{Material and Methods}

\section{Study area}

The rio Doce lake system originated in the Pleistocene during the Flandrian Transgression, which was characterized by high sea levels, arid climate and increased erosion (Meis $\&$ Monteiro, 1979). During that period, the main river channel captured adjacent drainages such as the rio Piracicaba, rio Suaçuí Grande, and rio São Mateus (Petri \& Fúlfaro, 1983). During this process, old riverbeds became isolated from the river and originated a complex and extensive lacustrine system (Petri \& Fúlfaro, 1983). The current lake system region is limited to latitudes $19^{\circ} 48^{\prime}-19^{\circ} 29^{\prime} \mathrm{S}$ and parallels $42^{\circ} 29^{\prime}-42^{\circ} 28^{\prime} \mathrm{W}$ (Fig. 1).

We collected 65 specimens ( 29 males and 36 females) from 8 lakes (Table 1). The specimens were transported alive to the laboratory and a commercial product with mitogenic activity (Molina, 2001) was injected twice before conducting cytogenetic protocols (Bertollo et al., 1978). Constitutive heterochromatin was detected following Sumner (1972). Nucleolar organizer regions (NORs) were visualized with silver nitrate following Howell \& Black (1980). Double $\mathrm{CMA}_{3}$ and DAPI fluorochrome technique was obtained following Carvalho et al. (2005). Images of metaphases were captured using an Olympus BX60 microscope and a DEI-470 CCD digital camera (Optronics). Chromosome measures were obtained using Image-Pro Plus 3.1 software (Media Cybernetics, 1998). Chromosomes were classified using the centromeric index as proposed by Levan et al. (1964). All specimens were deposited in the Museu de Zoologia da Universidade Federal de Viçosa, Viçosa, MG Brazil (MZUFV 3495, MZUFV 3524, MZUFV 3566, MZUFV 3598, MZUFV 3619, MZUFV 3646, MZUFV 3668, MZUFV 3669, MZUFV 3677, MZUFV 3723, MZUFV 3725, and MZUFV 3778).

\section{Results}

Besides a $2 n=42 \mathrm{~A}$ male collected in the Marola Lake, all the other trahiras showed typical $2 \mathrm{n}=42 \mathrm{~B}$ karyotypes (Bertollo et al., 2000) (Figs. 2A-B). The specimen with karyomorph A was characterized by 12 pairs of metacentrics and 9 pairs of submetacentrics. The specimens with karyomorph B also had 12 pairs of metacentrics, 8 pairs of submetacentrics and 1 pair of subtelocentrics in females and a heteromorphic pair (1 subtelocentric +-1 submetacentric) in males. The arm number was $\mathrm{NF}=84$ for both karyomorphs.

Nucleolar organizer regions showed high levels of variation in both karyomorphs, and their location was always telomeric. NOR number variation within individuals ranged from 2 to 7. Males always showed bitelomeric NORs, while these NORs appeared only in some females. NORs associated with sex chromosomes were less frequent (Fig. 3).

Sequential $\mathrm{CMA}_{3} / \mathrm{DAPI}$ showed pericentromeric and telomeric $\mathrm{CMA}_{3}+$ regions in some chromosomes, and NOR regions. Chromomycin showed strong fluorescence in the $\mathrm{X}$ chromosome of karyomorph B males, in sharp contrast to the single $2 n=42$ A specimen (Fig. 4).

Best C-banding results were obtained after 1 min exposure of slides to barium hydroxide solution at $42^{\circ} \mathrm{C}$. All chromosomes had centromeric heterochromatic blocks, whereas some chromosomes showed some telomeric blocks. Among-lake variations included size variation in $\mathrm{X}$ female 


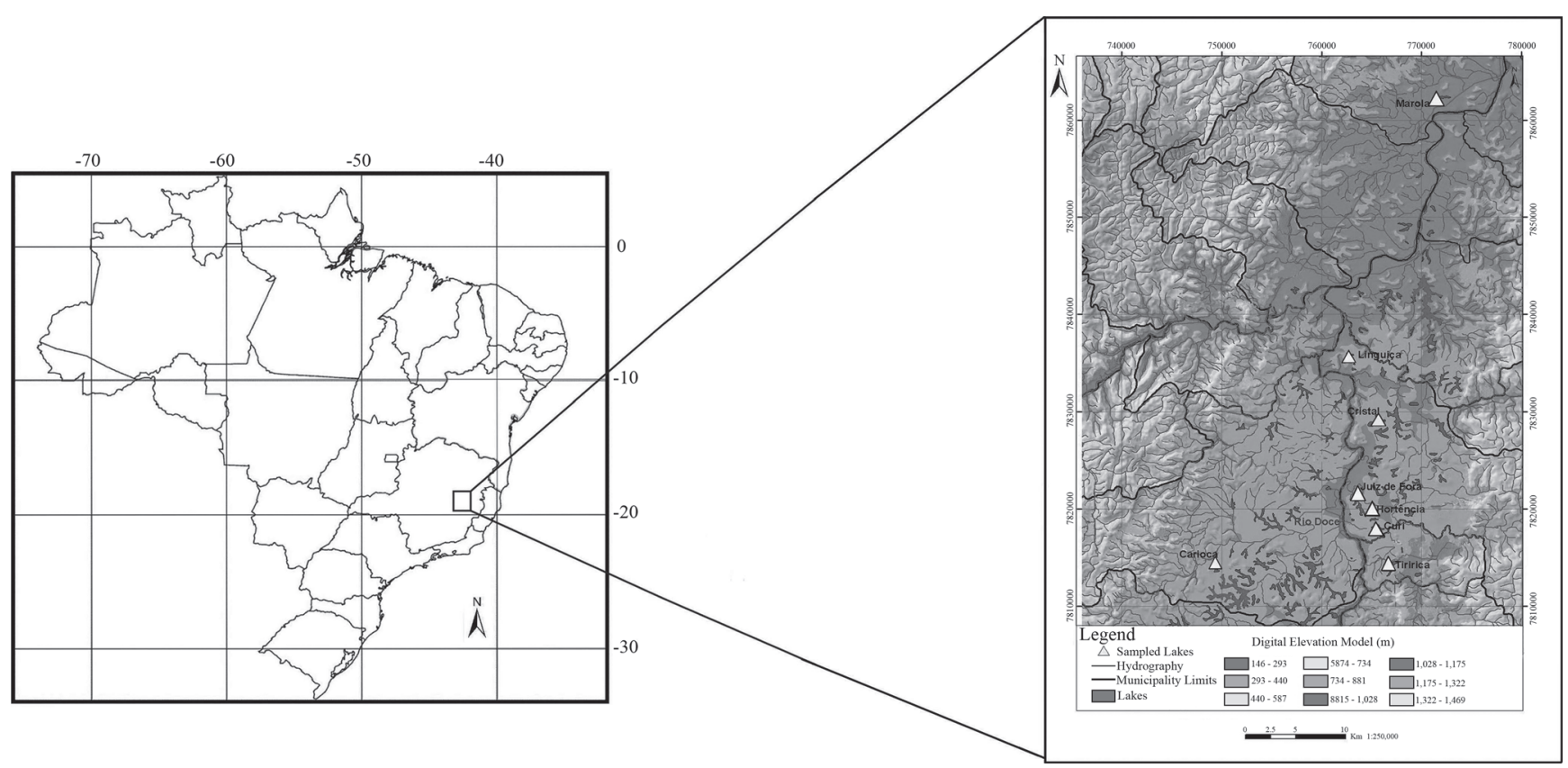

Fig. 1. Lacustrine system of the middle rio Doce. Triangles indicate sampled lakes.

chromosomes (Fig. 5). The most conspicuous variation involved the presence of bitelomeric blocks in pair No. 4 metacentrics (in Curi, Juiz de Fora, and Tiririca Lakes) and bitelomeric blocks in pair No. 10 metacentrics (in Curi, Cristal, Juiz de Fora, Linguiça, and Tiririca Lakes) (Figs. 5C- H). Other minor variations involved the absence of large heterochromatic centromeric blocks in submetacentrics of trahiras from the Linguiça Lake (Fig. 5F).

\section{Discussion}

The karyomorph $2 \mathrm{n}=42 \mathrm{~B}$ was prevalent in all studied lakes, as it is also reported for lagoa Ferrugem, lagoa Amarela, lagoa Azul, and laguna dos Patos (Ferreira et al., 1989; Born $\&$ Bertollo, 2000). The results allowed extending the sympatry of karyomorphs to the Marola Lake. Outside the rio Doce basin, karyomorph $2 \mathrm{n}=42 \mathrm{~A}$ is widespread in most southeastern Brazil, including neighbor coastal basins (Dergam, unpubl.), the rio Paraná basin, the rio Amazonas basin (Bertollo et al., 2000), and an isolated population in the headwater of a tributary the rio São Francisco (Santos et al., 2009).

The chromosomal rearrangements involving the differentiation $2 \mathrm{n}=42 \mathrm{~B}$ from a $2 \mathrm{n}=42 \mathrm{~A}$ ancestor are apparently simple (Ferreira et al., 1989): they resulted in the formation of sexual chromosomes $\mathrm{XX} / \mathrm{XY}$ and the transformation of a submetacentric chromosome into a subtelocentric one, probably through a pericentromeric inversion (Vicari et al., 2003). These authors proposed that $18 \mathrm{~S}$ cistrons associated to heterochromatin shared between the $\mathrm{X}$ chromosome and chromosome 16 of the $2 \mathrm{n}=42 \mathrm{~A}$ suggest a homeology between the two karyomorphs, an evolutionary change that according to the same authors, also involved changes in the repetitive DNA.
Data also indicated extensive among-population variation in NORs patterns and C-banding. Bi-telomeric NORs detected with silver nitrate were present in all samples, a characteristic trait for $2 \mathrm{n}=42$ trahiras within H. malabaricus (Born \& Bertollo, 2000, 2006; Lemos et al., 2002; Vicari et al., 2003, 2005). However, their frequency was sex-specific: they occurred in all 16 males, but only 14 out of 38 females, a sex bias unreported for other $H$. malabaricus populations. In fish, NORs detected with silver nitrate are usually associated to GC-rich regions and strong fluorescence $\mathrm{CMA}_{3}$ (Galetti \& Rasch, 1993; Mestriner et al., 1995), although this is not a strict condition (e.g., Artoni et al., 1999). Our results indicated that this pattern may not include bi-telomeric NORs, which consistently showed faint $\mathrm{CMA}_{3}$ fluorescence. In Gobius niger (Gobiidae) Mandrioli et al. (2001) report that regions marked with silver nitrate did not show fluorescence with $\mathrm{CMA}_{3}$. Within and between-individual NOR variation are interpreted as a reflection of transcriptional activity during the past interphase of individual cells (Pendas et al., 1993), and this transcriptional variation could explain the observed size differences among X chromosomes. Born \& Bertollo (2000) report high levels of in situ hybridization of an rDNA 18S

Table 1. Geographical location and sample sizes in lakes of the middle rio Doce Valley, MG, Brazil.

\begin{tabular}{|c|c|c|}
\hline Locality & GPS coordinates & $\begin{array}{c}\text { Sample size } \\
\text { (males/females) }\end{array}$ \\
\hline Marola Lake & $19^{\circ} 19^{\prime} 05.33157^{\prime \prime S} 42^{\circ} 25^{\prime} 05.07202^{\prime \prime O}$ & $(0 / 3)$ \\
\hline Linguiça Lake & 19³3'26.11000”S 42²9’47.49000”O & $(2 / 2)$ \\
\hline Cristal Lake & 19³6'57.11000”S 42²8'06.69000”O & $(5 / 3)$ \\
\hline Juiz de Fora Lake & 1941'49.49310”S 42²9’08.29559”O & $(2 / 3)$ \\
\hline Curi Lake & $19^{\circ} 42^{\prime} 11.64000 ” \mathrm{~S} 42^{\circ} 27^{\prime} 44.61000^{\prime \prime O}$ & $(3 / 8)$ \\
\hline Hortência Lake & 1942’14.55080”S 42²6’04.09600”O & $(2 / 5)$ \\
\hline Tiririca Lake & $19^{\circ} 45^{\prime} 02.92000^{\prime \prime} \mathrm{S} 42^{\circ} 27^{\prime} 15.30000^{\prime \prime O}$ & $(5 / 6)$ \\
\hline Carioca Lake & $19^{\circ} 45^{\prime} 32.44840^{\prime \prime} \mathrm{S} 42^{\circ} 37^{\prime} 15.54440^{\prime \prime} \mathrm{O}$ & $(10 / 6)$ \\
\hline
\end{tabular}



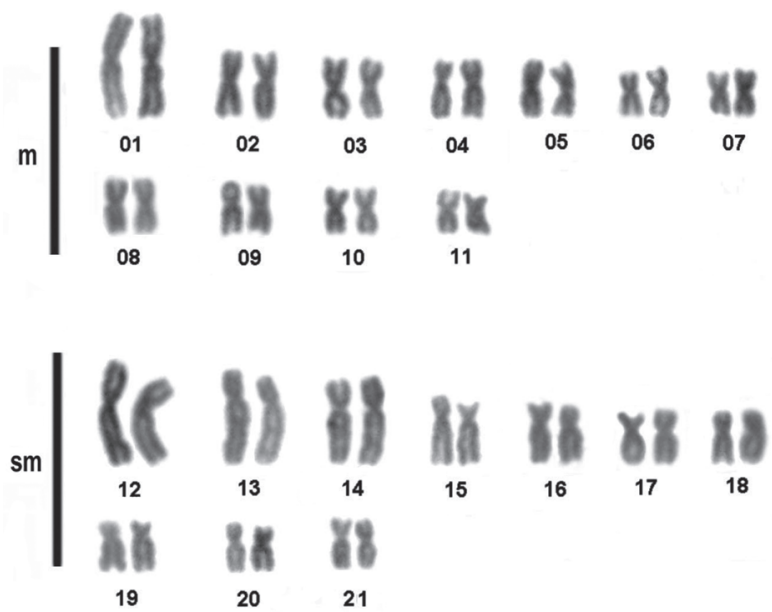

Karyomorph A
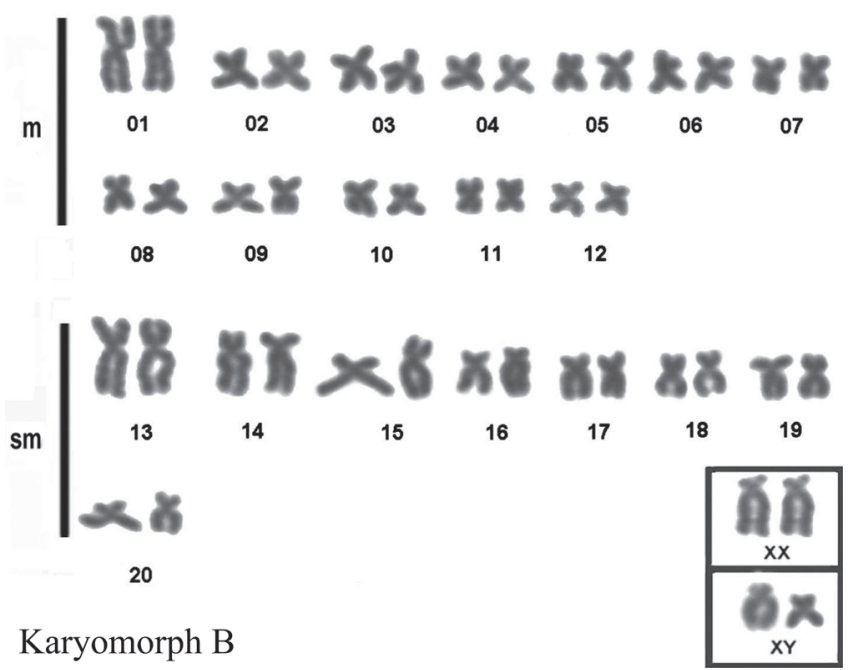

Fig. 2. Giemsa-stained H. malabaricus karyomorphs from middle rio Doce lakes, MG, Brazil.

probe, which also included the subtelocentric X chromosome. These authors also reported size variation in NORs and in the heterochromatic GC-rich segments. Our results indicated that patterns of heterochromatin were efficient as populational markers in this lacustrine system. Although heterochromatin has been regarded as highly relevant in the karyotypic evolution of fishes (Ojima \& Ueda, 1979), most studies of heterochromatin variation in Neotropical fishes have not been interpreted in a temporal context. Although the heterochromatin has been traditionally considered as devoid of genetic information, the evolutionary role of heterochromatin (Djupedal \& Ekwall, 2008) is currently subject to debate. Many studies focus on the transcriptional feature of the lack of access of RNA polymerase II to this type of heterochromatin (Djupedal \& Ekwall, 2008). Allshire (2002) indicates that centromeric heterochromatin may play a crucial role in cell division. Dernburg et al. (1996) indicate that heterochromatin could play a role in nuclear architecture and in genic expression, due to the position-effect phenomenon
(Pardue \& Henning, 1990). On the other hand, John (1988) suggests that heterochromatin variation would be negative for some organisms, mainly due to the mechanisms that bring about these changes, such as multiple replication, unilateral amplification and deletion. John (1988) indicates that heterochromatic blocks inhibit chiasmata formation, even though this does not hold for Allium (Loidl, 1982). In the species complex Mus terricolor, Sharma et al. (2003) observed variation in the heterochromatin in the short arms of autosomes, which would prevent synaptic association during meiosis. These authors describe this phenomenon as dosedependent and as a potentially critical factor for anomalies, which would be relevant in speciation processes. Heterochromatin may also harbor transposable elements (Dimitri \& Junakovic, 1999) and meiotic mobility factors (Lyttle, 1993) that could potentially play a significant role in speciation, by reducing the meiotic ability in hybrids and acting as a fertility barrier (Shaw, 1994; Dimitri \& Junakovic, 1999). Redi (2001) also suggests that heterochromatin would be involved in speciation. Within-population heterochromatin variation has been reported for Astyanax scabripinnis (Mantovani et al., 2000) and among-population variation has been observed in $H$. malabaricus populations from the rio Tibagi and rio Iguaçu (Vicari et al., 2003), and in Leporinus elongatus from the Tibagi (Molina et al., 2008). However, Sumner (2003) indicates that the relation between heterochromatin and chromosome pairing and crossing-over has been not demonstrated consistently and therefore it is not possible to assign a clear function to this type of chromatin.

$\mathrm{CMA}_{3}$ and DAPI patterns revealed some chromosomal aspects that were not evident with C-banding and Ag-NOR techniques, such as telomeric blocks in submetacentrics that were fluorescent with chromomycin and were therefore CGrich regions not associated to rDNA. Association between heterochromatic blocks and NORs was also evident, which may occur separated by a distinctive region, or tightly linked, as in Leporinus desmostes (Margarido \& Galleti, 2000) According to Redi et al. (1990) GC-rich regions are prone to a high rate of recombination and could encourage mergers or centric fissions. This also seems to be the case for species Hoplias malabaricus.

Although speciation must be viewed as a process, the Pleistocene isolation of $H$. malabaricus populations has apparently promoted differentiation of C-banding and fluorochrome patterns in the middle rio Doce Valley, a condition that had already been reported by Dergam et al. (2002) for some lakes, based on RAPD molecular data. Furthermore, our results suggested that lacustrine populations of $H$. malabaricus may be facing independent ecological and evolutionary processes and they should be considered as independent units of management and conservation. So far, speciation process linked to the lake formation has been proposed for only 1 small predatory characin, the lake-dwelling Oligosarcus solitarius, and its riverine sister species, Oligosarcus argenteus (Menezes, 1987). 


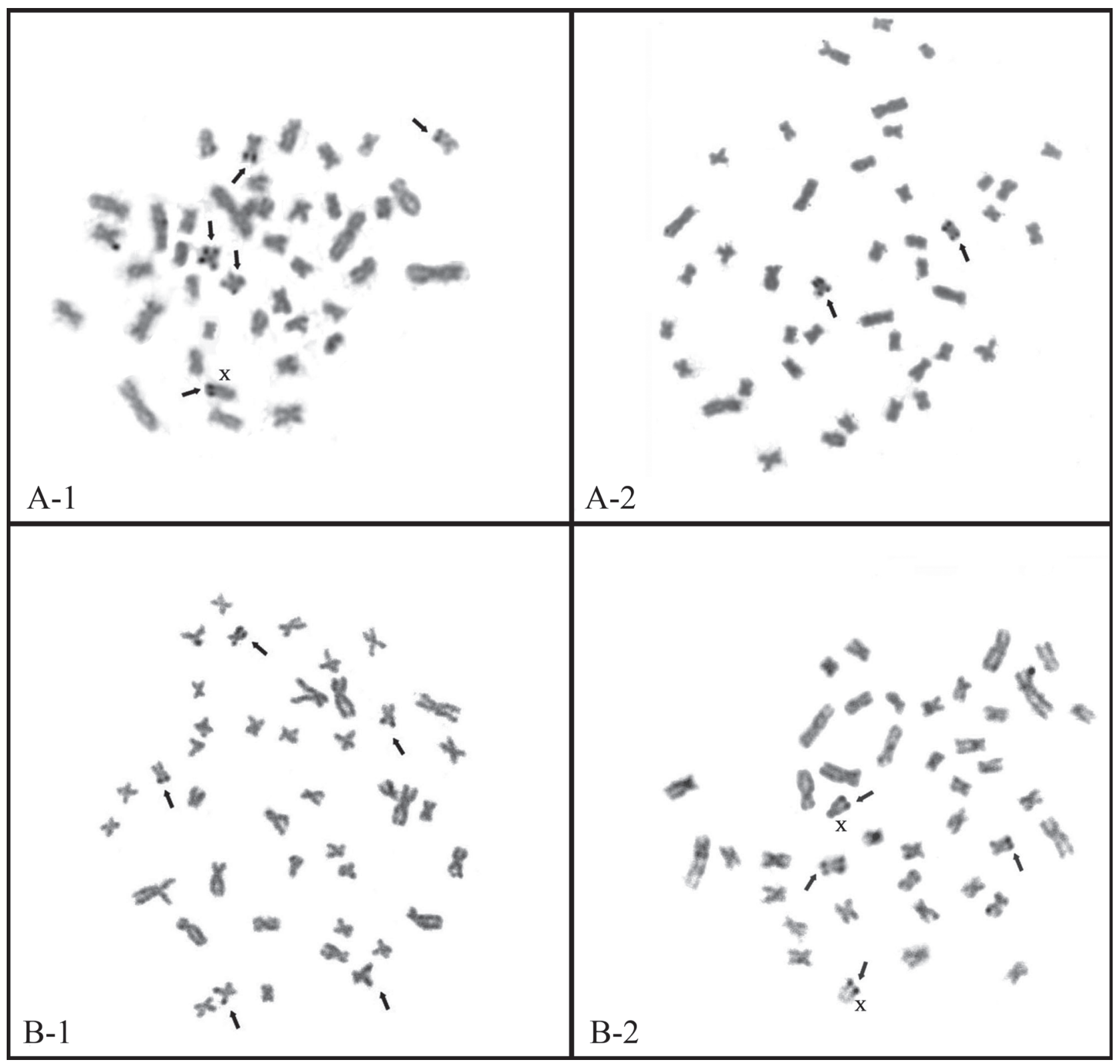

Fig. 3. Variable Ag-NOR patterns in populations of $H$. malabaricus from middle rio Doce lakes. A-1, A-2, and B1, B-2 male and female NORs.
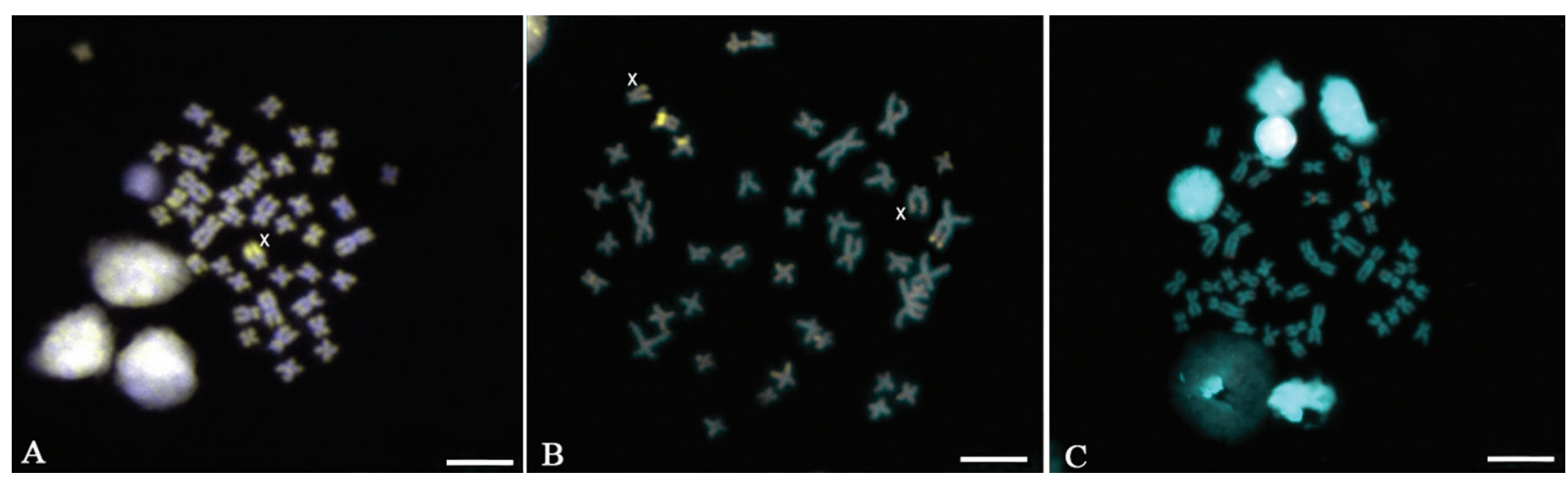

Fig. 4. Patterns of GC-rich regions in H. malabaricus from middle rio Doce lakes. A - karyomorph B male, B - karyomorph B female, and $\mathbf{C}$ - karyomorph A. 


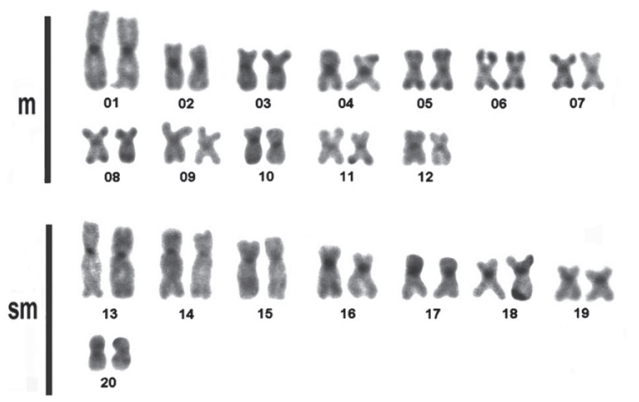

A - Carioca

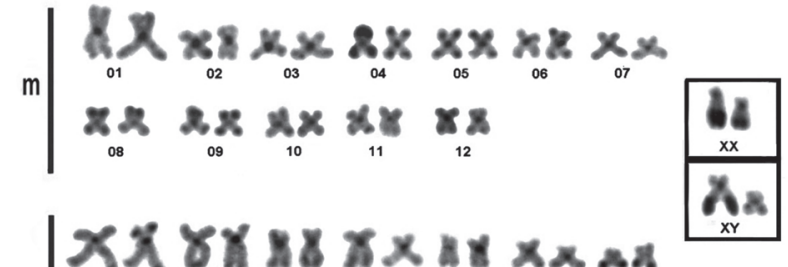

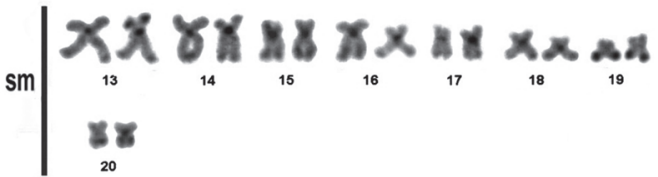

C - Curi

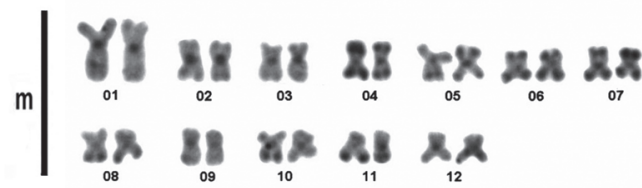

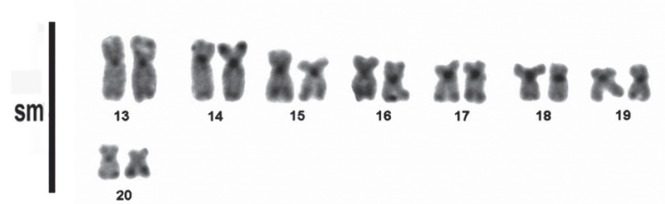

E - Juiz de Fora

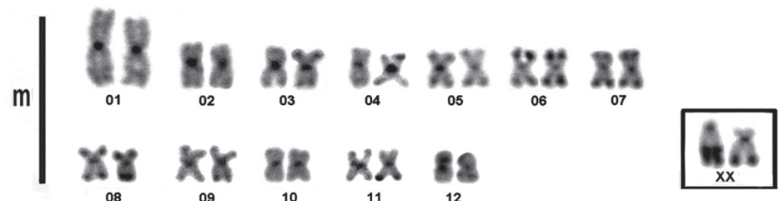

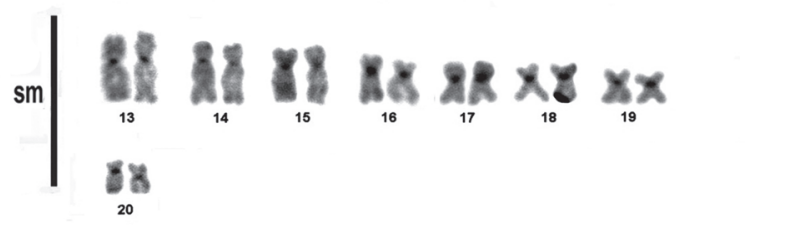

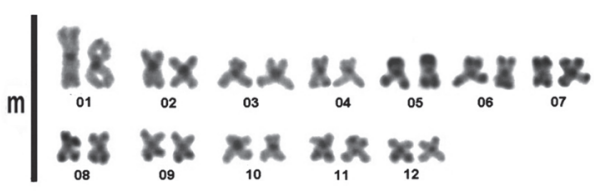

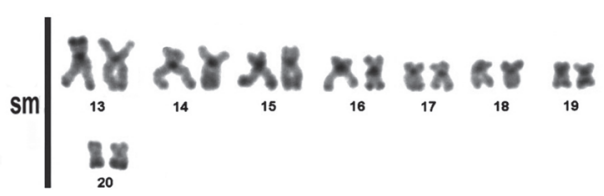

\begin{tabular}{|l|}
\hline$x$ \\
\hline$x x$ \\
\hline$x y$ \\
\hline$x y$
\end{tabular}

B - Hortência

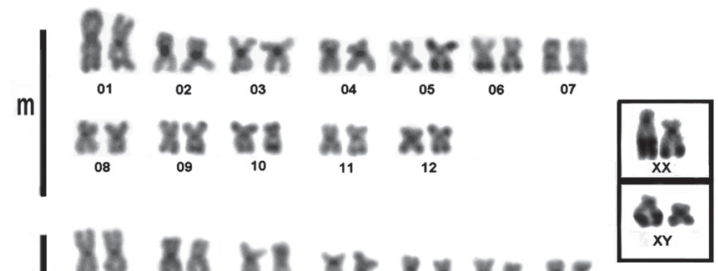

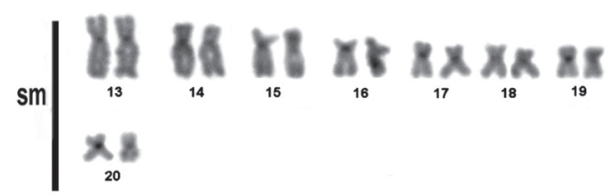

D - Cristal

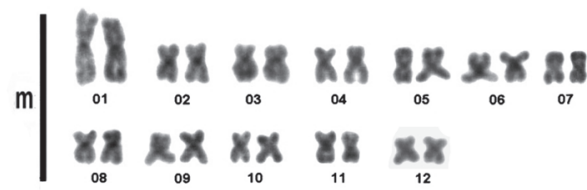

$\operatorname{sm} \mid \begin{aligned} & \underset{13}{8} \\ & \times_{20} \times\end{aligned}$

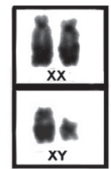

F - Linguiça

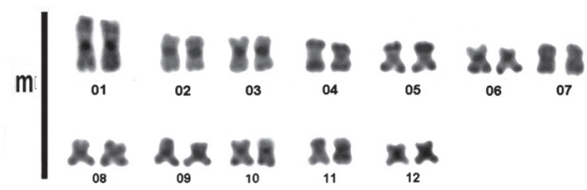

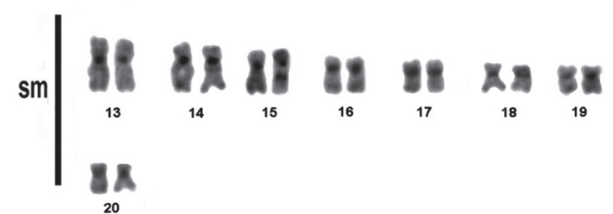

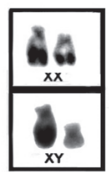

G - Marola

H - Tiririca

Fig. 5. C-banding patterns of $H$. malabaricus populations. Lake names are indicated. 
Pleistocene speciation is a matter of debate. McCune (1997) proposed a specific active speciation role for young lakes in eastern Africa. Among them, Lake Victoria has been considered as a model for explosive speciation in the last 14,600 years (e.g., Kaufman et al., 1997; McCune, 1997; Seehausen et al., 1997). This interpretation has been challenged by studies that consider Lake Victoria as a recent assemblage that incorporated an older and already lineage-diverse scenario that preceded lake formation (Fryer, 2001; Seehausen, 2002). Weitzman \& Weitzman (1982) also consider that the Pleistocene refuge theory is particularly poor to explain Neotropical fish diversity, and Lundberg et al. (1998) suggest that the Neotropical fish fauna was already modern in the Miocene.

The ubiquity of karyomorph $2 n=42 B$ raised questions that must be addressed in the future, such as potential gene flow between these karyomorphs, or the existence of a replacement process driven by selective advantages of the karyomorph $2 \mathrm{n}=42 \mathrm{~B}$ in the lake system. Although the massive impact caused by the presence of exotic species such as peacock bass Cichla piquiti, piranhas Pygocentrus nattereri, the African walking catfish Clarias gariepinus, and the Amazonian Oscar Astronotus ocellatus may represent a strong selective pressure on these lacustrine fish communities. These results and previous studies (Ferreira et al., 1989; Born \& Bertollo, 2006) indicate that karyomorph $2 \mathrm{n}=42 \mathrm{~B}$ is also more abundant in lakes that keep native fish communities therefore relative abundance of karyomorph $2 n=42 B$ may be due to older selective or non-selective factors. Karyomorph $2 \mathrm{n}=42 \mathrm{~A}$ may face small population dynamics such as the Allee Effect (Stephens et al., 1999), where males and females may not encounter for reproduction, a critical aspect for the nesting building behavior of this species (Prado et al., 2006).

\section{Acknowledgements}

The authors wish to thank Celulose Nipo-Brasileira CENIBRA for financial and logistic support. Partial financial support was obtained from Conselho Nacional de Desenvolvimento Científico e Tecnológico CNPq (Process: 403304/2005-9) to Jorge Dergam.

\section{Literature Cited}

Allshire, R. 2002. RNAi and heterochromatin - a hushed-up affair. Science, 297: 1818-1819.

Artoni, R. F., W. F. Molina, L. A. C. Bertollo, P. M. Galetti Jr. 1999. Heterochromatin analysis in the fish species Liposarcus anisitsi (Siluriformes) and Leporinus elongatus (Characiformes). Genetics and Molecular Biology, 22: 39-44.

Avise, J. C. 2000. Phylogeography: The history and formation of species. Harvard University Press, Cambridge, Massachusetts.

Beheregaray, L. 2008. Twenty years of phylogeography: the state of the field and the challenges for the Southern Hemisphere. Molecular Ecology, 17: 3754-3774.

Berra, T. M. 2007. Freshwater Fish Distribution. University of Chicago Press, 615p.
Bertollo, L. A. C., G. G. Born, J. A. Dergam, A. S. Fenocchio \& O. Moreira-Filho. 2000. A biodiversity approach in the Neotropical Erythrinidae fish, Hoplias malabaricus. Karyotypic survey, geographic distribution of cytotypes and cytotaxonomic considerations. Chromosome Research, 8: 603-613.

Bertollo, L. A. C., C. S. Takahashi \& O. Moreira-Filho. 1978. Cytotaxonomic considerations on Hoplias lacerdae (Pisces, Erythrinidae). Brazilian Journal of Genetics, 1: 103-120.

Born, G. G. \& L. A. C. Bertollo. 2000. An XX/XY sex chromosome system in a fish species, Hoplias malabaricus with a polymorphic NOR-bearing X chromosome. Chromosome Research, 8: 111-118.

Born, G. G. \& L. A. C. Bertollo. 2006. A new sympatric region for distinct karyotypic forms of Hoplias malabaricus (Pisces, Erythrinidae). Brazilian Journal of Biology, 66: 205-21.

Carvalho, R., W. S. Soares-Filho, A. C. Brasileiro-Vidal \& M. Guerra. 2005. The relationships among lemons, limes and citron: a chromosomal comparison. Cytogenetics Genome and Research, 109: 276-282.

Dergam, J. A., S. R. Paiva, C. E. Schaefer, A. L. Godinho \& F. Vieira. 2002. Phylogeography and RAPD-PCR variation in Hoplias malabaricus (Bloch, 1974) (Pisces, Teleostei) in southeastern Brazil. Genetics and Molecular Biology, 25: 379-387.

Dernburg, E. M., K. W. Broman, J. C. Fung, W. L. Marshal, J. Philips, D. A. Agard \& J. W. Sedat. 1996. Perturbation of nuclear architecture by long-distance chromosome interactions. Cell, 85: 754-759.

Djupedal, I. \& K. Ekwal. 2008. The paradox of silent heterochromatin. Science, 5876: 624-625.

Dimitri, P. \& N. Junakovic. 1999. Revising the selfish DNA hypothesis: new evidence on accumulation of transposable elements in heterochromatin. Trends in Ecology and Evolution, 15: 123-124.

Espíndola, E. L. G., M. B. C. Branco, R. Fracácio, A. M. Guntzel, E. M. Moretto, R. H. G. Pereira, A. C. Rietzler, O. Rocha, S. Roggther, W. S. Smith \& S. K. Tavares. 2003. Organismos aquáticos. Pp. 202-238. In: Rambaldi, D. M. \& D. A. S. Oliveira (Orgs.). Fragmentação de Ecossistemas $2^{\circ} \mathrm{Ed}$. Ministério do Meio Ambiente, Biodiversidade. Brasília, 510p.

Ferreira, R. H. R., C. G. Fonseca, L. A. C. Bertollo \& F. Foresti. 1989. Cytogenetics of fishes from Parque Florestal do Rio Doce (MG). I. Preliminary study of "Hoplias malabaricus" (Pisces, Erythrinidae) from Lagoa Carioca and Lagoa dos Patos. Brazilian Journal of Genetics, 12: 219-226.

Fryer, G. 2001. On the age and origin of the species flock of haplochromine cichlid fishes of Lake Victoria. Proceedings of the Royal Society of London, 268: 1147-1152.

Galetti Jr., P. M. \& E. M. Rasch. 1993. NOR variability in diploid and triploid forms at the Amazon molly Poecilia formosa as shown by silver nitrate and chromomycin $\mathrm{A}_{3}$ staining. Brazilian Journal of Genetics, 16: 927-938.

Godinho, A. L., M. T. Fonseca \& L. M. Araújo. 1994. The ecology of predator fish introductions: the case of Rio Doce valley lakes. Pp. 77-83. In: Pinto-Coelho, R. M., A. Giani \& V. E. Sperling (Eds.). Ecology and Human Impact on Lakes and Reservoirs in Minas Gerais with Special Reference to Future Development and Management Strategies. Belo Horizonte, SEGRAC, 193p.

Godinho, A. L. \& F. Vieira. 1998. Ictiofauna. Áreas prioritárias para a conservação da biodiversidade do Estado de Minas Gerais. Pp. 44-46. In: Costa, C. M. R., G. Hermann, C. S. Martins, L. V. Lins \& I. R. Lamas (Eds.). Biodiversidade em Minas Gerais: um Atlas para sua Conservação. Fundação Biodiversitas, Belo Horizonte, 222p. 
Gold, J. R., Y. C. Li, N. S. Shipley \& P. K. Powers. 1990. Improved methods for working with fish chromosomes with a review of metaphase chromosome banding. Journal of Fish Biology, 37: 563-575.

Graur, D. \& W. H. Li. 2000. Fundamentals of Molecular Evolution. $2^{\circ}$ Ed. Sinauer Associates, Sunderland, Massachusetts.

Howell, W. M. \& D. A. Black. 1980. Controlled silver-staining of nucleolus organizer regions with a protective colloidal developer: a 1-step method. Experientia, 36: 1014-1015.

John, B. 1988. The biology of heterochromatin. Pp. 1-147. In: Verma, R. S. (Ed.). Heterochromatin: Molecular and Structural Aspects. Cambridge University Press, New York, 320p.

Kaufman, L. S., L. J. Chapman \& C. A. Chapman. 1997. Evolution in fast forward: haplochromine fishes of the Lake Victoria region. Endeavour, 21: 23-30.

Latini, A. O. 2005. Inventário rápido e identificação de variáveis que limitam a dispersão de exóticos: um estudo sobre peixes no médio rio Doce (MG, Brasil). Unpublished Ph.D. Thesis, Universidade Estadual de Campinas, Campinas, 115p.

Latini, A. O. \& M. Petrere. 2004. Reduction of native fish fauna by alien species: an example from Brazilian freshwater tropical lakes. Fisheries Management Ecology, 11: 71-79.

Lemos, P. M. M., A. S. Fenocchio, L. A. C. Bertollo \& M. M. Cestari. 2002. Karyotypic studies on two Hoplias malabaricus populations (Characiformes, Erythrinidae) of the $2 n=42$ group, from the first plateau of the Iguaçu river basin (Paraná State, Brazil). Caryologia, 55: 193-198.

Levan, A., K. Fredga \& A. A. Sandberg. 1964. Nomenclature for centromeric position on chromosomes. Hereditas, 52: 201-220.

Loidl, J. 1982. Further evidence for a heterochromatin-chiasma correlation in some Allium species. Genetica, 60: 31-35.

Lundberg, J. G., L. G. Marshall, J. Guerrero, B. Horton, M. C. S. L. Malabarba \& F. Wesselingh. 1998. The stage for Neotropical fish diversification: a history of tropical South America rivers. Pp.13-48. In: Malabarba, L. R., R. E. Reis., R. P. Vari., Z. M. S. Lucena \& C. A. S. Lucena (Eds.). Phylogeny and Classification of Neotropical Fishes. Porto Alegre, Edipucrs, 603p.

Lyttle, T. W. 1993. Cheaters sometimes prosper: distortion of Mendelian segregation by meiotic drive. Trends in Genetics, 9: 205-210.

Mandrioli, M., G. C. Manicardi, N. Machella \& V. Caputo. 2001. Molecular and cytogenetic analysis of the Gobius niger (Teleostei, Gobiidae). Genetica, 110: 73-78.

Mantovani, M., L. D. S. Abel, C. A. Mestriner \& O. Moreira-Filho. 2000. Accentuated polymorphism of heterochromatin and nucleolar organizer regions in Astyanax scabripinnis (Pisces, Characidae): tools for understanding karyotypic evolution. Genetica, 109: 161-168.

Margarido, V. P. \& P. M. Galetti Jr. 2000. Amplification of a GCrich heterochromatin in the freshwater fish Leporinus desmotes (Characiformes, Anostomidae). Genetics and Molecular Biology, 23: 569-573.

McCune, A. 1997. How fast is speciation? Molecular, geological, and phylogenetic evidence from adaptive radiations of fishes. Pp. 585-610. In: Givnish, T. J. \& K. J. Sytsma (Eds.). Molecular Evolution and Adaptive Radiation. Cambridge University Press, New York, 621p.

Meis, M. R. M. \& A. M. F. Monteiro. 1979. Upper Quaternary "rampas", Rio Doce Valley: S. E. Brazilian plateau. Zusammenfassun für Geomorphologie, 23: 132-151.

Meis, M. R. M. \& J. R. S. Moura. 1984. Upper Quaternary sedimentation and hillslope evolution: SE Brazilian plateau. American Journal of Science, 284: 241-254.
Menezes, N. A. 1987. Três espécies novas de Oligosarcus Günther, 1864 e redefinição taxonômica das demais espécies do gênero (Osteichthyes, Teleostei, Characidae). Boletim de Zoologia São Paulo, 11: 1-39.

Mestriner, C. A., L. A. C. Bertollo \& P. M. Galetti Jr. 1995. Chromosome banding and synaptonemal complexes in Leporinus lacustris (Pisces, Anostomidae): analysis of a sex system. Chromosome Research, 3: 440-443.

MMA/SBF. 2000. Avaliação e Ações Prioritárias Para a Conservação da Biodiversidade da Mata Atlântica e Campos Sulinos. Ministério do Meio Ambiente. MMA/SBF, Brasília, 40p.

Molina, W. F. 2001. An alternative method of mitotic stimulation in fish cytogenetics. Chromosome Science, 5: 149-152.

Molina, W. F., O. A. Shibatta \& P. M. Galetti Jr. 2008. Chromosomal evidence of population subdivision in the freshwater fish Leporinus elongatus in the Upper Paraná River basin. Genetics and Molecular Biology, 31: 270-274.

Montoya-Burgos, J. I. 2003. Historical biogeography of the catfish genus Hypostomus (Siluriformes: Loricariidae), with implications on the diversification of Neotropical ichthyofauna. Molecular Ecology, 12: 1855-1867.

Myers, G. S. 1938. Fresh-water fishes and West Indian zoogeography. Annual Reports Smithsonian Institution, 1937.

Ojima, Y. \& T. Ueda. 1979. New C-banded marker chromosomes found in carp-funa hybrids. Proceedings of the Japan Academy, 54: $15-20$

Page, R. D. M. \& E. C. Holmes. 1998. Molecular Evolution: a Phylogenetic Approach. Blackwell Science Ltd, 346p.

Pardue, M. L. \& W. Hennig. 1990. Heterochromatin, junk or collector's item?. Chromosoma, 100: 3-7.

Pendas, A., P. Moran \& E. G. Vázquez. 1993. Multi-chromosomal location of ribosomal RNA genes and heterochromatin association in brown trout. Chromosome Research, 1: 63-67.

Petri, S. \& V. J. Fúlfaro. 1983. Quaternário, região do médio rio Doce. Pp. 472-474. In: Geologia do Brasil. Minas Gerais, Edusp, $63 \mathrm{p}$.

Pinto-Coelho, R. M., J. F. Bezerra-Neto, F. Miranda, T. G. Mota, R. Resck, A. M. Santos, P. M. Maia-Barbosa, N. A. S. T. Mello, M. M. Marques, M. O. Campos \& F. A. R. Barbosa. 2008. The inverted trophic cascade in tropical plankton communities: impacts of exotic fish in the Middle Rio Doce lake district, Minas Gerais, Brazil. Brazilian Journal of Biology, 68: 10251037.

Prado, C. P., L. M. Gomiero \& O. Froelich. 2006. Spawning and parental care in Hoplias malabaricus (Teleostei, Characiformes, Erythrinidae) in the Southern Pantanal, Brazil. Brazilian Journal of Zoology, 66: 697-702.

Redi, C. A., S. Garagna, H. Zacharias, M. Zuccotti \& E. Capanna. 2001. The other chromatin. Chromosoma, 110: 136-147.

Redi, C. A., S. Garagna \& M. Zuccotti. 1990. Robertsonian chromosome formation and fixation: the genomic scenario. Biological Journal of the Linnean Society, 41: 235-255.

Rosa, R. 2006. Estudos citogenéticos em diferentes populações de Hoplias malabaricus (Characiformes, Erythrinidae). Unpublished M.Sc. Dissertation, Universidade Estadual de Londrina. Londrina, 126p.

Santos, U., C. M. Völcker, F. A. Belei, M. B. Cioffi, L. A. C. Bertollo, S. R. Paiva \& J. A. Dergam. 2009. Molecular and karyotypic phylogeography in the Neotropical Hoplias malabaricus (Erythrinidae) fish in eastern Brazil. Journal of Fish Biology, 75: 2326-2343. 
Schaefer, S. A. 1998. Conflict and resolution: impact of new taxa on phylogenetic studies of the Neotropical cascudinhhos (Siluroidei: Loricariidae). Pp. 375-400. In: Malabarba, L. R., R. E. Reis, R. P. Vari, Z. M. S. Lucena \& C. A. S. Lucena (Eds.). Phylogeny and Classification of Neotropical Fishes. Porto Alegre, Edipucrs, 603p.

Seehausen, O. 2002. Patterns in fish radiation are compatible with Pleistocene desiccation of Lake Victoria and 14600 year history for its cichlid species flock. Proceedings of the Royal Society of London, 269: 491-497.

Seehausen, O., J. J. M. van Alphen \& F. Witte. 1997. Cichlid fish diversity threatened by eutrophication that curbs sexual selection. Science, 277: 1808-1811.

Sharma, T., A. Bardhan \& M. Bahadur. 2003. Reduced meiotic fitness in hybrids with heterozygosity for heterochromatin in the speciating Mus terricolor complex. Journal of Biosciences, 28: 189-198.

Shaw, D. D. 1994. Centromeres: moving chromosomes through space and time. Trends in Ecology and Evolution, 9: 170-175.

Sivasundar, A., E. Bermingham \& G. Ortí. 2001. Population structure and biogeography of migratory freshwater fishes (Prochilodus: Characiformes) in major South American rivers. Molecular Ecology, 10: 407-417.

Stephens, P. A., W. J. Sutherland \& R. P. Freckleton. 1999. "What is the Allee effect?". Oikos, 87: 185-90.

Sumner, A. T. 1972. A simple technique for demonstrating centromeric heterochromatin. Experimental Cell Research, 75: 304-306.
Sumner, A. T. 2003. Chromosomes: Organization and Function. Blackwell Publishing, London, 287p.

Sunaga, T. \& J. R. Verani. 1985. Preliminary report of comparative study on fish community of the Rio Doce lakes. Pp. 167-174. In: Water Research Institute, Limnological Studies in Central Brazil ( $1^{\text {st }}$ Report). Nagoya University, Chikusa-ku, Nagoya, Japan.

Tundisi, J. G. \& M. R. M. De Meis. 1985. Geomorphology and limnological processes at the Middle Rio Doce Valley lakes. Pp. 11-17. In: Water Research Institute, Limnological Studies in Central Brazil ( $1^{\text {st }}$ Report). Nagoya University, Chikusa-ku, Nagoya, Japan.

Vicari, M. R., R. F. Artoni \& L. A. C. Bertollo. 2003. Heterochromatin polymorphism associated with $18 \mathrm{~S}$ rDNA. A differential pathway among Hoplias malabaricus fish populations. Cytogenetics and Genome Research, 101: 24-28.

Vicari, M. R., R. F. Artoni \& L. A. C. Bertollo. 2005. Comparative cytogenetics of Hoplias malabaricus (Pisces, Erythrinidae): a population analysis in adjacent hydrographic basins. Genetics and Molecular Biology, 28: 103-110.

Vono, V. \& F. A. R. Barbosa. 2001. Habitats and littoral zone fish community structure of two natural lakes in southeast Brazil. Environmental Biology of Fishes, 61: 371-379.

Weitzman, S. H. \& M. Weitzman. 1982. Biogeography and evolutionary diversification in Neotropical freshwater fishes, with comments on the refuge theory. Pp. 403-422. In: Prance, T. G. Biological Diversification in the Tropics. (Ed.). Columbia University Press, New York, 714p. 